\title{
EDUKASI PENGGUNAAN SUPLEMEN KESEHATAN PADA IBU-IBU PKK DI MASA PANDEMI COVID-19 WILAYAH DESA PEMECUTAN KAJA, KECAMATAN DENPASAR UTARA, KOTA DENPASAR
}

\author{
Dhiancinantyan Windydaca Brata Putri'1), Ni Putu Wintariani'1), Dewi Puspita Apsari'1), \\ Ni Putu Aryati Suryaningsih")
}

1)Program Studi Farmasi Klinis, Fakultas Ilmu Kesehatan, Universitas Bali Internasional, Denpasar, Bali, Indonesia

Corresponding author : Dhiancinantyan Windydaca Brata Putri

E-mail : windydacabrataputri@iikmpbali.ac.id

Diterima 26 November 2021, Disetujui 30 November 2021

\begin{abstract}
ABSTRAK
Pemerintah pusat terus menggalakkan pencegahan dan pengendalian Covid-19, melalui Gugus Tugas COVID-19. Salah satu cara untuk menjaga daya tahan tubuh dari serangan virus corona adalah dengan mengkonsumsi vitamin atau suplemen. Informasi vitamin/suplemen yang akan disebarkan pada pengabdian masyarakat ini adalah vitamin C, Zink, dan Vitamin D3 di wilayah Desa Pemecutan Kaja, Kecamatan Denpasar Utara, Kota Denpasar dengan sasaran ibu-ibu PKK. Tujuan dari pengabdian masyarakat ini adalah memberikan edukasi terkait pentingnya mengkonsumsi suplemen kesehatan dimasa pandemi COVID-19 dan bagaimana mengkonsumsi suplemen/vitamin dimasa pandemi COVID19. Metode kegiatan ini dengan memberikan edukasi berupa poster secara langsung dan e-booklet melalui whatsapp grup kepada ibu-ibu PKK dan pengukuran pengetahuan dilakukan sebelum dan setelah pemberian edukasi. Hasil yang didapatkan adalah terdapat peningkatan pengetahuan ibu PKK secara signifikan $(p=0,000)$ yakni dari skor baik semula berjumlah $19 \%$ meningkat menjadi $98 \%$ partisipan. Data tersebut menunjukkan bahwa tujuan dari program kerja tercapai, yaitu peningkatan pengetahuan partisipan ibu-ibu PKK terhadap penggunaan suplemen kesehatan di masa pandemi covid-19.
\end{abstract}

Kata kunci: edukasi; suplemen; covid-19.

\begin{abstract}
The central government continues to promote the prevention and control of Covid-19, through the COVID-19 task force. One way to maintain the immune system from the corona virus is to take vitamins or supplements. Information on vitamins/supplements that will be distributed in this community service is vitamin C, Zink, and Vitamin D3 in the Pemecutan Kaja Village area, North Denpasar District, Denpasar City with the target of PKK women. The purpose of this activity is to provide education regarding the importance of consuming health supplements during the COVID-19 pandemic and how to take supplements/vitamins during the COVID-19 pandemic. The method of this activity is to provide education in the form of direct posters and e-booklets via whatsapp groups to PKK women and knowledge measurements are carried out before and after providing education. The results obtained were that there was a significant increase in the knowledge of PKK women $(p=0.000)$, namely from the original good score of $19 \%$, it increased to $98 \%$ of participants. The data shows that the goal of the work program was achieved, namely increasing the knowledge of PKK women on the use of health supplements during the COVID-19 pandemic.
\end{abstract}

Keywords: education; supplements; covid-19.

\section{PENDAHULUAN}

Tahun 2019 menjadi awal tahun yang berat bagi dunia, tahun 2019 awal ditemukancorona viruses (CoV) atau yang biasa disebut dengan COVID-19. Corona viruses (CoV) merupakan bagian dari keluarga virus yang menyebabkan penyakit mulai dari flu hingga penyakit yang lebih berat seperti Middle East Respiratory Syndrome (MERS-CoV) and Severe Acute Respiratory Syndrome (SARS-CoV) (World
Health Organization, 2019). Penyakit ini teridentifikasi belum pernah menyerang manusia, penyebaran yang sangat cepat ini menyebabkan beberapa kerugian yang diderita seluruh dunia. WHO pada tanggal 11 maret 2020, menetapkan status virus corona sebagai pandemi dunia. Semua negara terkena dampak dari covid-19 ini (Widiyani, 2020).

Penyebaran virus ini menyebar melalui droplet batuk dan bersin dari penderita. Daya 
tahan virus di plastik dan stailess steel, bisa mencapai tiga hari atau dalam aerosol selama tiga jam (Kemendagri, 2020). Kasus corona di indonesia mencapai 4.174.216 orang hingga 15 September 2021. Berdasarkan data Worldometer, jumlah kasus virus corona di Indonesia tersebut menjadi yang terbesar keempat di Asia. Angka prevalensi yang tinggi ini menyebabkan perekonomian dan tingkat kesejahteraan sosial di indonesia semakin menurun. Angka kemiskinan di indonesia semakin meningkat karena pandemi COVID-19. Khususnya di Bali angka kasus virus corona yang tinggi menyebabkan sektor pariwisata dibali mengalami penurunan yang tajam. Bebrapa pencegahan COVID-19, dilakukan dengan cara cuci tangan menggunakan air mengalir dan sabun, makan makanan yang bergizi, menggunakan masker yang benar, menjaga jarak dan menjauhi keramaian (Kemenkes RI, 2020).

Menjaga daya tahan tubuh dari Covid19 adalah dengan mengkonsumsi vitamin atau suplemen. Mengkonsumsi makanan yang mengandung vitamin atau mengkonsumsi suplemen yang ada di pasaran untuk menjaga imunitas tubuh. Kandungan antioksidan di dalam sayur dan buah membantu meningkatkan imunitas tubuh, sehingga dapat membantu dalam pencegahan Covid-19 (Kemenkes RI, 2020). Vitamin dan mineral yang berfungsi menjaga daya tahan tubuh diantaranya adalah vitamin C, Zink, dan Vitamin D3. Pengabdian masyarakat yang akan dilakukan akan menyebarkan informasi vitamin/suplemen. Pengabdian masyarakat dilaksanakan di daerah Denpasar Utara, pemilihan Denpasar utara, Desa Pemecutan Kaja, dikarenakan data yang dihimpun dari aplikasi pendulilindungi per-tanggal 31 Agustus 2021, Desa Pemecutan Kaja termasuk dalam zona Resiko Tinggi COVID-19 (Corona Virus Disease-19). Kemudian, berdasarkan data yang dihimpun dari website Desa Pemecutan Kaja (Kaja, 2021), per-tanggal 31 Agustus 2021, jumlah kasus COVID-19 yang sembuh berjumlah total 1039, sisa kasus positif 59 orang, kasus per-rumah 52 orang, serta kasus meninggal 29 orang. Dari ke-13 dusun, hanya 5 dusun termasuk dalam zona hijau dengan jumlah kasus positif kurang dari 3, yakni Semilajati, Balun, Panti Gede, Belong Gede, dan Belong Menak. Sedangkan, dusun lain terdapat dalam zona kuning dengan jumlah kasus positif aktif 3-10 orang dengan dusun Merthayasa jumlah kasus terbanyak.

Beberapa pengabdian masyarakat dan penelitian dilakukan mengenai suplemen untuk menjaga daya tahan tubuh, beberapa diantaranya yaitu pengabdian dengan topik
Peningkatan Kesehatan dengan Suplemen dan Gizi Seimbang di Era Pandemi Covid-19, dimana pada pengabdian masyarakat ini diharapkan hasil berupa adanya peningkatan pengetahuan mengenai pengetahuan mengenai konsumsi suplemen dan vitamin yang rasional di masa pandemi Covid-19, akan tetapi masih harus terus dievaluasi (kartini lidia dkk, 2020). Pengabdian mayarakat yang dilakukan di daerah NTB, dimana didapatkan hasil pengabdian yaitu masyarakat kurang paham dalam mengkonsumsi suplemen dan vitamin. Beberapa masyarakat mengkonsumsi suplemen dengan merk dagang yang berbeda namun mengandung zat aktif yang sama. Saat masyarakat diberikan penjelasan terkait vitamin dan suplemen, didapatkan hasil postest akhirnya mereka memahami bahwa tidak semua suplemen tersebut harus mereka konsumsi secara bersama-sama (Baiq Nurbaety, 2021).

\section{METODE}

Kegiatan pengabdian masyarakat dilakukan dengan cara melakukan penyuluhan dan memberikan edukasi terkait pentingnya mengkonsumsi suplemen kesehatan dimasa pandemi COVID-19 dan bagaimana mengkonsumsi suplemen/vitamin dimasa pandemi COVID-19 di wilayah Desa Pemecutan Kaja, Kecamatan Denpasar Utara, Kota Denpasar. Sasaran pengabdian masyarakat ini adalah ibu-ibu PKK sejumlah 59 orang/partisipan/responden.

Sasaran atau target akan diberikan pretest dan postest terkait dengan tema dalam meningkatkan pengetahuan masyarakan dalam upaya pencegahan covid-19, yang berjudul "Edukasi Penggunaan Suplemen Kesehatan pada IBU-IBU PKK di Masa Pandemi Covid-19 wilayah Desa Pemecutan Kaja, Kecamatan Denpasar Utara, Kota Denpasar". Pemberian pretest dan postest ini bertujuan untuk melihat atau mengetahui tingkat pemahaman terkait dengan hal tersebut, maka pretest diberikan sebelum dilakukannya edukasi, kemudian setelah diberikannya edukasi akan dilanjutkan dengan pemberian postest. Sehingga tujuan dari dilakukannya edukasi ini dapat tercapai dengan memberikan informasi tersebut baik secara langsung maupun melalui e-booklet atau poster yang disampaikan dan diberikan kepada ibu-ibu PKK. Edukasi diberikan secara langsung dengan mendatangi rumah rumah warga dan mereka juga diberikan link booklet yang akan diberikan dalam bentuk link, yang dimana link tersebut dapat diakses kapanpun sehingga lebih bermanfaat kapan saja dan dimana saja. Sedangkan poster akan dibagikan secara langsung saat melakukan door to door. 
Kegiatan diawali dengan berkunjung kepada pihak terkait dilokasi penelitian tersebut. Kemudian dilanjutkan dengan observasi baik secara langsung maupun melalui daring mengenai bagaimana kondisi di lapangan, kemudian menganalisa masalah yang ada agar dapat mengetahui apa saja yang dibutuhkan di lingkungan tersebut. Selanjutnya membuat rancangan kegiatan dalam bentuk proposal dan melakukan pengurusan ijin.

Kegiatan pengabdian masyarakat dilakukan dengan berbagai tahap yang dapat dijabarkan, sebagai berikut :

a. Pre-test : Pemberian Pre Test disini guna melihat tentang gambaran pengetahuan awal peserta sebelum diberikan edukasi. Pretest diberikan dalam bentuk kuisioner, yang dimana di dalam kuisioner tersebut menyangkut beberapa pertanyaan terkait dengan judul yang telah ditetapkan. Kuisioner tersebut dapat dijadikan sebagai bahan evaluasi akhir setelah melakukan edukasi terkait dalam pentingnya mengkonsumsi suplemen kesehatan dimasa pandemi COVID-19

b. Edukasi : Edukasi dilakukan secara door to door dengan menggunakan poster yang diberikan secara langsung atau disebarkan secara langsung kepada lbuIbu PKK, poster ini dibuat dalam edukasi mengenai pentingnya mengkonsumsi suplemen Kesehatan dimasa pandemi COVID-19, selain itu edukasi juga diperkuat dengan pemberian e-booklet yang diberikan dalam bentuk link yang kemudian dapat disebarkan melalui Whatsapp Group ibu-ibu PKK.

c. Post-test : Post Test disini bertujuan untuk melihat seberapa jauh tingkat pengetahuan dan pemahaman terhadap apa yang telah disampaikan baik secara langsung yang diperkuat dengan pemberian link tersebut mengenai edukasi pentingnya mengkonsumsi suplemen Kesehatan dimasa pandemi dan bagaimana mengkonsumsi suplemen/vitamin dimasa pandemi COVID-19.

\section{HASIL DAN PEMBAHASAN}

Pelaksanaan Pengabdian $\begin{gathered}\text { Kepada } \\ \text { tentang } \\ \text { Masuarakat (PKM) }\end{gathered}$
penggunaan suplemen dilakukan di wilayah
Desa Pemecutan Kaja, Kecamatan Denpasar
Utara, Kota Denpasar. Wilayah Desa
Pemecutan Kaja terdiri dari 13 banjar, yakni
Banjar Kerthasari, Kerthajati, Semilajati,
Tulangampiang, Margajati, Mekar Manis,
Mertha Yasa, Balun, Belong Gede, Belong
Menak, Gerenceng, Panti Sari, serta Panti

Gede. Dari ke-13 banjar tersebut, hanya 5 banjar yang masuk ke dalam zona hijau untuk jumlah kasus positif sedangkan sisanya masuk ke dalam zona kuning (Kaja, 2021). Melihat bahwa Desa Pemecutan Kaja masih termasuk dalam zona resiko tinggi dengan sebagian besar dusun berada dalam zona kuning, maka diperlukan suatu program kerja mengenai pencegahan COVID-19. Observasi dilakukan dengan 4 tokoh masyarakat, yakni Kepala Desa Pemecutan Kaja, Kepala Dusun Balun, Bagian Kesehatan Desa Pemecutan Kaja serta Bagian Pengolah Data Kasus COVID-19 Desa Pemecutan Kaja. Sasaran program kerja adalah ibu-ibu PKK dengan jumlah 59 orang/partisipan/responden. Hal ini disebabkan, wanita lebih peduli terhadap lingkungan dan kesehatannya, sehingga mampu meningkatkan pencegahan terhadap suatu penyakit di dalam keluarga (Suhardin, 2016).

Pelaksanaan program kerja ini dilakukan selama 13 hari terhitung dari tanggal 7 September-19 September 2021 karena jumlah banjar yang berada di lingkungan Pemecutan Kaja berjumlah 13. Pelaksanaan kegiatan ini terdiri atas 5 tahapan diantaranya pengisian absensi partisipan, pretest, penyuluhan materi, posttest, dan pembagian masker medis serta suplemen kesehatan. Pengisian absensi partisipan dilakukan sebagai daftar hadir partisipan yang dimana sudah disiapkan kolom per-banjar untuk memudahkan dalam memproses data. Selain itu, digunakan pula sebagai tanda bukti kegiatan karena disertai tanda tangan partisipan. Kemudian, partisipan akan diminta untuk menjawab kuesioner pretest. Tahapan ini bertujuan untuk menggali pengetahuan partisipan mengenai COVID-19 dan suplemen kesehatan dengan memberikan kuesioner.

Lembaran kuesioner pretest dan posttest diberikan dalam bentuk kertas guna memudahkan partisipan untuk menjawab sesuai gambar 1. Namun, beberapa partisipan dibacakan karena menderita rabun dekat. Tingkat pengetahuan dikelompokkan menjadi 3 , yaitu pengetahuan kurang jika partisipan dapat menjawab dengan tepat sebanyak 0 sampai 3 pertanyaan, pengetahuan cukup jika partisipan dapat menjawab dengan tepat sebanyak 4 sampai 7 pertanyaan, dan pengetahuan baik jika partisipan dapat menjawabn pertanyaan dengan tepat sebanyak 8 sampai 10 pertanyaan. 


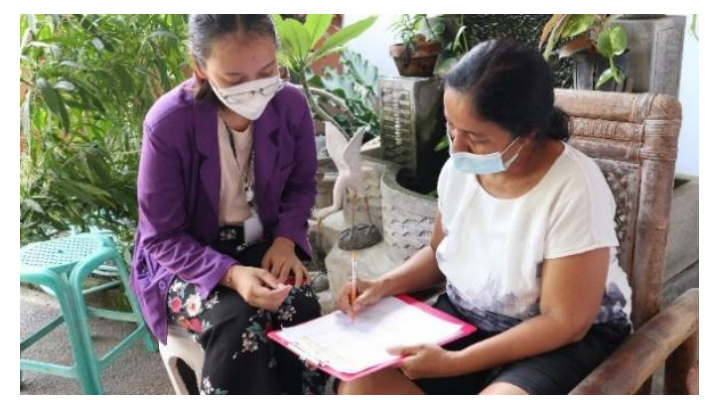

Gambar 1. Pengisian Kuesioner oleh lbu-lbu PKK Sebagai Partisipan

Kuesioner terdiri atas 10 butir pertanyaan yang harus dijawab oleh setiap peserta sebelum (pretest) dan sesudah (posttest) kegiatan penyuluhan diberikan. Partisipan menentukan jawaban dengan memilih apakah partisipan menjawab benar atau salah terhadap pernyataan di kuesioner tersebut. Jawaban partisipan kemudian dikoreksi untuk mengetahui tingkat pengetahuan partisipan. Setelah kuesioner pretest dikerjakan oleh partisipan, kemudian dilakukan pemberian edukasi atau penyuluhan mengenai suplemen kesehatan yang tepat di era COVID-19 menggunakan media poster.

Poster tersebut berisi manfaat suplemen kesehatan; mitos yang salah terkait penggunaan suplemen kesehatan; fakta penggunaan suplemen kesehatan; sumber, manfaat dan batasan dosis dari penggunaan vitamin C, D, E, dan Zink; serta prinsip pemilihan suplemen kesehatan dengan cek "KLIK" sesuai gambar 2. Dilanjutkan dengan pemberian e-booklet yang diberikan dalam bentuk link yang kemudian dapat disebarkan melalui Whatsapp Group ibu-ibu PKK. Edukasi e-booklet ini berisi tentang materi yang ada di dalam poster. Sehingga dapat digunakan dalam sosialisasi kegiatan ibu-ibu PKK. Seluruh meteri informasi yang disampaikan tersebut didapatkan dari Buku Saku Suplemen Kesehatan BPOM RI. Penyuluhan tersebut dapat berlangsung 10-15 menit, kemudian poster tersebut akan diserahkan kepada partisipan untuk dapat disimpan dan dijadikan acuan informasi dalam menggunakan suplemen kesehatan.

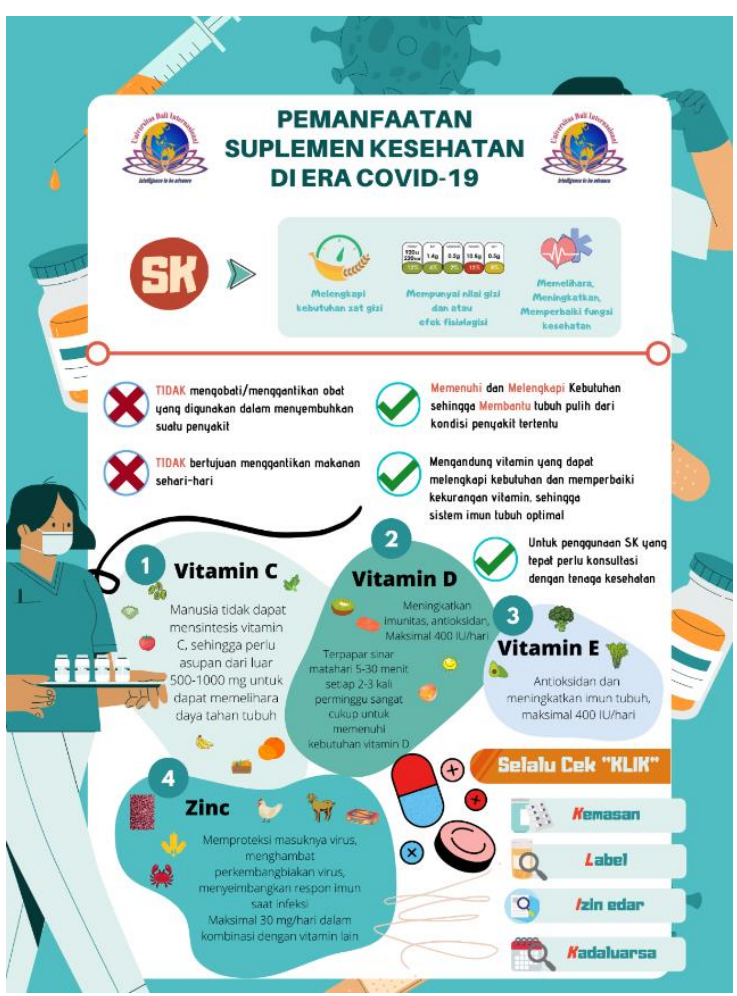

Gambar 2. Penyuluhan Edukasi Suplemen Melalui Media Poster

Kegiatan selanjutnya adalah pembagian kuesioner posttest kepada partisipan untuk mengetahui peningkatan pengetahuan setelah dilakukan pemberian materi penyuluhan. Pada tabel 1. terlihat karakteristik responden ibu PKK yang terlibat dalam PKM. Berdasarkan data pada tabel 1 terlihat mayoritas responden berusia 36-45 tahun, memiliki tingkat pendidikan terakhir sarjana dan bekerja pada sektor swasta dengan angka 20 (34\%), 46 (78\%) dan 29 (49\%) secara berturut-turut.

Tabel 1. Karakteristik Responden yang Terlibat dalam PKM

\begin{tabular}{lc}
\hline \multicolumn{1}{l}{ Karakteristik Demografi } & $\mathrm{N}(\%)$ \\
\hline Usia (tahun) & \\
$26-35$ & $23(39)$ \\
$36-45$ & $20(34)$ \\
$46-55$ & $15(25)$ \\
$>56$ & $1(2)$ \\
\hline Tingkat pendidikan & $9(15)$ \\
SMA & $4(7)$ \\
Diploma & $46(78)$ \\
Sarjana & \\
\hline Pekerjaan & $17(29)$ \\
IRT & $7(12)$ \\
PNS & $29(49)$ \\
Swasta & $6(10)$ \\
Tidak bekerja & \\
&
\end{tabular}

Hal ini menunjukkan bahwa ibu PKK di wilayah Desa Pemecutan Kaja, termasuk dalam 
usia produktif dan dengan melihat tingkat pendidikan dan pekerjaan, diharapkan ibu PKK dapat menerima dan mengaplikasikan edukasi penggunaan suplemen kesehatan terutama di masa pandemi Covid-19.

Selanjutnya setelah dilakukan kegiatan pretest dan postest, dilakukan analisa data dengan Wilcoxon signed rank test untuk mengetahui perbedaan skor responden sebelum dan sesudah diberikan edukasi. Hasil tersebut dapat dilihat pada tabel 2 .

Tabel 2. Perbandingan Skor Edukasi Responden Setelah diberikan Edukasi

\begin{tabular}{cccc}
\hline $\begin{array}{c}\text { Tingkat } \\
\text { Pengetahuan }\end{array}$ & $\begin{array}{c}\text { Skor } \\
\text { Pretest } \\
\mathrm{N}(\%)\end{array}$ & $\begin{array}{c}\text { Skor } \\
\text { Postest } \\
\mathrm{N}(\%)\end{array}$ & $\begin{array}{c}P \text { - } \\
\text { Value }\end{array}$ \\
\cline { 1 - 3 } Baik & $11(19)$ & $58(98)$ & 0,000 \\
\cline { 1 - 3 } Cukup & $46(78)$ & $1(2)$ & \\
\cline { 1 - 3 } Kurang & $2(3)$ & $0(0)$ &
\end{tabular}

Berdasarkan tabel 2. terlihat terjadi peningkatan pengetahuan ibu PKK secara signifikan $(p=0,000)$ yakni dari skor baik semula berjumlah $19 \%$ meningkat menjadi $98 \%$ partisipan. Data tersebut menunjukkan bahwa tujuan dari program kerja tercapai, yaitu peningkatan pengetahuan partisipan ibu-ibu PKK. Hal ini sejalan dengan penelitian yang dilakukan oleh Dea, 2021, dimana media edukasi dapat meningkatkan pengetahuan dalam mencegah penularan penyakit tidak menular di masa pandemi Covid-19 (Marbun et al., 2021). Beberapa penelitian lainnya juga menunjukkan bahwa media poster merupakan salah satu media yang dapat meningkatkan pengetahuan masyarakat terhadap kesehatan pada masa pandemi Covid-19 (Nataprawira et al., 2018; Sulistyowati, 2019; Suriadi \& Kurniasari, 2017)

Berdasarkan hasil koreksi tingkat pengetahuan suplemen diketahui bahwa semua partisipan benar pada pernyataan bahwa COVID-19 adalah penyakit yang tumbuh di saluran pernafasan dan vitamin $C, D$, $\mathrm{E}$ membantu meningkatkan sistem imun tubuh. Hal tersebut menunjukkan bahwa seluruh masyarakat sangat paham akan pengertian dari COVID-19 juga vitamin-vitamin yang dapat meningkatkan imun tubuh. $\mathrm{Hal}$ ini sesuai dengan penelitian yang dilakukan oleh Kurnia, 2020, menunjukkan bahwa pengetahuan masayarakat dalam konsumsi vitamin selama masa pandemi Covid-19 sudah baik (Winingsih et al., 2020; Wulandri*, 2000)

Pernyataan dengan jawaban salah terbanyak pada pretest ialah pernyataan suplemen yang dibutuhkan saat kondisi Pandemi COVID-19 hanyalah Suplemen yang mengandung Vitamin C. Hal tersebut menggambarkan bahwa sebagian besar partisipan mengetahui hanya vitamin $\mathrm{C}$ sebagai suplemen kesehatan yang dibutuhkan di kondisi COVID-19 ini. Padahal, selain suplemen yang mengandung vitamin $\mathrm{C}$, juga dibutuhkan suplemen yang mengandung vitamin D, E, dan Zink. Penelitian Rivan, 2020, menunjukkan bahwa pengetahuan masyarakat tentang vitamin $D$ sebagai suplemen kesehatan sangatlah kurang, sehingga perlu edukasi kepada masyarakat tentang vitamin D (Suryadinata et al., 2020). Sedangkan, pernyataan dengan jawaban salah terbanyak pada posttest ialah pernyataan suplementasi zink dibutuhkan dalam kondisi Covid-19, selain mampu meningkatkan fungsi imun di usus, juga dapat mengurangi gejala flu. Hal tersebut menunjukkan bahwa partisipan masih belum memahami adanya manfaat atau peran zink terhadap gejala flu. Masyarakat lebih banyak menggunakan zinc dalam pengobatan diare ataupun peningkatan gizi pada balita dibandingkan untuk mencegah penyakit Covid19 (Budiastutik et al., 2011; Illahi et al., 2016). Beberapa penelitian menunjukkan manfaat dari vitamin $D$, Vitamin $E$ dan Zinc terhadap pencegahan Covid-19 terutama pada ibu hamil (Alexander et al., 2020; Anggraini \& Anjani, 2021; Azizah \& Fatmawati, 2020; Kotur et al., 2021)

Kegiatan pengabdian masyarakat ini dilanjutkan dengan pemberian masker medis dan suplemen kesehatan sebagai ucapan terima kasih kepada partisipan yang bersedia meluangkan waktunya dalam melakukan program kerja ini sesuai gambar 3 .

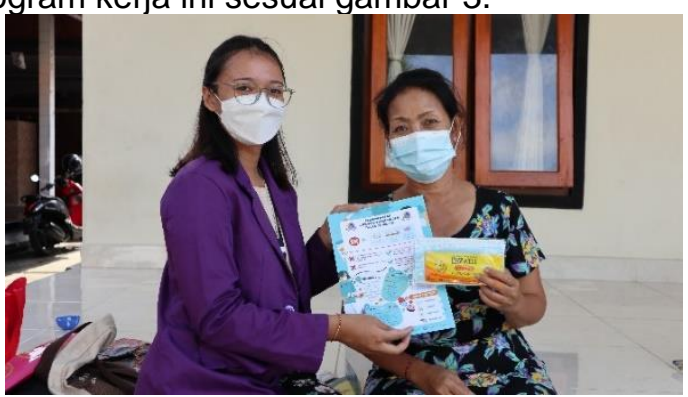

Gambar 3. Pemberian Masker Medis dan Suplemen Kesehatan

Kegiatan pengabdian masyarakat ini diharapkan dapat memberikan informasi ini kepada masyarakat lainnya dalam ikut serta mencegah penularan Covid-19 melalui ibu-ibu PKK. Hal ini disebabkan ibu-ibu PKK merupakan salah satu pemberi informasi dan pelindung kesehatan keluarga dari penyakit.

\section{SIMPULAN DAN SARAN}

Kegiatan pengabdian masyarakat di Desa Pemecutan Kaja menunjukkan bahwa media edukasi berupa poster dapat meningkatkan pengetahuan partisipan ibu-ibu 
PKK mengenai suplemen kesehatan pada masa pandemi Covid-19. Saran dalam kegiatan pengabdian masyarakat ini diharapkan dapat terus berlangsung dengan tema suplemen kesehatan lainnya yang dapat meningkatkan pengetahuan masyarakat dalam mencegah penularan Covid-19.

\section{UCAPAN TERIMAKASIH}

Ucapan terimakasih diberikan kepada ibu-ibu PKK di wilayah Desa Pemecutan Kaja yang berpartisipasi dalam kegiatan ini, Lembaga Penelitian dan Pengabdian kepada Masyarakat (LPPM) Universitas Bali Interansional yang telah mendanai kegiatan pengabdian ini dan adik-adik mahasiswa Program Studi Farmasi Klinis yang ikut membantu dalam kegiatan ini, sehingga kegiatan dapat berjalan dengan lancar.

\section{DAFTAR RUJUKAN}

Kaja, P., 2021. Desa Pemecutan Kaja. [Online] Available at: https://pemecutankaja.denpasarkota.go.id /berita/read/29252

[Accessed 319 No Kegiatan Bulan September 2021].

Kartini lidia, Elisabeth Levina Sari Setianingrum, Conrad Folamauk, Magdarita Riwu, Anita Lidesna Shinta Amat. Peningkatan Kesehatan dengan Suplemen dan Gizi Seimbang di Era Pandemi Covid-19, Jurnal Pengabdian Masyarakat LPPM UNDANA, 14(2), 63-68. Retrieved from http://ejurnal.undana.ac.id/index.php/ilpp $\mathrm{m} /$ article/view/3445.

Kemenkes RI (2020) Infeksi Emerging Kementerian Kesehatan RI. Available at: https://covid19.kemkes.go.id/situasiinfeksi-emerging/situasi-terkiniperkembangan-novel-coronavirus-2019ncov-10-februari-2020

Kementerian Dalam Negeri Republik Indonesia. Pedoman Umum Menghadapi Pandemi Covid-19 Bagi Pemerintah Daerah. Jakarta2020 [cited 202017 September]. Available from: https://www.kemendagri.go.id/documents/ covid-

19/Buku_Pedoman_Covid19_Kemendagri .pdf

Alexander, J., Tinkov, A., Strand, tor a, Alehagen, U., Skalny, A., \& Aaseth, J. (2020). Early Nutritional Interventions with Zinc, Selenium Against Progressive COVID-19. Nutrients, 12(8), 1-12.

Anggraini, N. N., \& Anjani, R. D. (2021). Kebutuhan Gizi Ibu Hamil pada Masa Pandemi Covid-19. Jurnal Pangan Dan Gizi, 11(1), 42-49.
https://jurnal.unimus.ac.id/index.php/JPD G/article/view/7491

Azizah, N., \& Fatmawati, D. A. (2020). Nutrisi Saat Kehamilan Di Masa Pandemi COVID-19. Jurnal EDUNursing, 4(2), 93102.

http://journal.unipdu.ac.id:8080/index.php /edunursing/article/view/2321

Budiastutik, I., Wirjatmadi, B., \& Adriani, M. (2011). Konsentrasi Zinc Rambut Balita ( Program Mp Asi Biskuit Di Kertosono Jawa Timur ). Buletin Penelitian Sistem Kesehatan, 14(3), 270-281.

Illahi, R. K., P, F. F., \& Sidharta, B. (2016). PHARMACEUTICAL JOURNAL OF INDONESIA Tingkat Pendidikan Ibu dan Penggunaan Oralit dan Zinc pada Penanganan Pertama Kasus Diare Anak Usia 1-5 Tahun: Sebuah Studi di Puskesmas Janti Malang The Correlation of Mother' s Education Level and the Usage of Orali. Pharmaceutical Journal of Indonesia, 2(1), 1-6.

Kotur, N., Skakic, A., Klaassen, K., Gasic, V., Zukic, B., Skodric-Trifunovic, V., Stjepanovic, M., Zivkovic, Z., Ostojic, O., Stevanovic, G., Lavadinovic, L., Pavlovic, S., \& Stankovic, B. (2021). Association of Vitamin D, Zinc and Selenium Related Genetic Variants With COVID-19 Disease Severity. Frontiers in Nutrition, 8(June), 110.

https://doi.org/10.3389/fnut.2021.689419

Marbun, R., Sugiyanto, S., \& Dea, V. (2021). Edukasi Kesehatan Pada Remaja Dalam Pentingnya Gizi Seimbang Dan Aktivitas Fisik Di Era Pandemi Covid-19. SELAPARANG Jurnal Pengabdian Masyarakat Berkemajuan, 4(3), 508. https://doi.org/10.31764/jpmb.v4i3.4494

Nataprawira, H. M. N., Wayan, I., \& Handisurya, A. (2018). efektivitas intervensi media poster terhadap pengetahuan, sikap, dan perilaku masyarakat mengenai tuberkulosis di kecamatan cimerak, pangandaran, JaWa barat heda melinda $n$. nataprawira, dan $i$ Wayan andrew handisurya. 7(4), 280-284.

Nurbaety, B., Rahmawati, C., Nopitasari, B. L., Qiyaam, N., Wardani, A. K., Pradiningsih, A., \& Wahid, A. R. (2021). Edukasi Bijak Dalam Memilih Dan Menggunakan Suplemen Pada Masa Pandemi Covid-19. SELAPARANG Jurnal Pengabdian Masyarakat Berkemajuan, 4(2), 469. https://doi.org/10.31764/jpmb.v4i2.4482

Suhardin, S. (2016). Pengaruh Perbedaan Jenis Kelamin Dan Pengetahuan Tentang Konsep Dasar Ekologi Terhadap Kepedulian Lingkungan. EDUKASI: Jurnal 
Penelitian Pendidikan Agama Dan Keagamaan, 14(1), 117-132. https://doi.org/10.32729/edukasi.v14i1.15

Sulistyowati, A. M. (2019). Pengaruh Penyuluhan Dan Media Poster Tentang Anemia Terhadap Tingkat Pengetahuan Dan Sikap Pada Santriwati (Studi Di Pondok Pesantren Al-Bisyri Kota Semarang). Jurnal Kesehatan Masyarakat (e-Journal), 7(4), 700-707.

Suriadi, \& Kurniasari, L. (2017). Pengaruh Media Poster Terhadap Pengetahuan Dan Sikap Tentang Diare Studi Kasus Pada Siswa Kelas IV 003 Palaran Kota Samarinda. Borneo Student Research, 1(1), 314-319.

Suryadinata, R. V., Lorensia, A., \& Wahyuningtyas, D. (2020). Studi Tingkat Pengetahuan Mengenai Vitamin D pada Pengemudi Becak di Surabaya. CoMPHI Journal: Community Medicine and Public Health of Indonesia Journal, 1(1), 15-21. https://doi.org/10.37148/comphijournal.v1 i1.4

Winingsih, P. A., Sulandjari, S., Indrawati, V., Soeyono, R. D., Masyarakat, J. K., David Laksamana Caesar, D. L. C., Nataprawira, H. M. N., Wayan, I., Handisurya, A., Suriadi, Kurniasari, L., Yuliawati, K., Djannah, S. N., Setyawati, V. A. V., Zahrina, M. D., General, R., Status, T., Dan, G., Nurbaety, B., ... Dea, V. (2020). Bagaimana Pengetahuan, Sikap Dan Perilaku Masyarakat Tentang Konsumsi Multivitamin/ Supplement Selama Pandemi Covid-19? Jurnal Kesmas (Kesehatan Masyarakat) Khatulistiwa, 7(1), 280-284. https://doi.org/10.29406/jkmk.v7i3.2077

Wulandri*, S. (2000). ANALISIS PENGETAHUAN MASYARAKAT TENTANG PENGGUNAAN VITAMIN C DALAM MENINGKATKAN IMUNITAS TUBUH SEBAGAI PENCEGAH CORONAVIRUS DISEASE (COVID-19). $1-12$.

World Health Organization (2020) WHO Director-General's remarks at the media briefing on 2019-nCoV on 11 February 2020. Available https://www.who.int/directorgeneral/speeches/detail/who-directorgeneral-s-remarks-at-the-media-briefingon-2019. 